\title{
EHMTI-0346. Do nurses improve migraine management in primary care?
}

\author{
P van den Berg ${ }^{1 *}, B$ Kollen ${ }^{2}, P$ Veenstra ${ }^{3}, G$ de Jong ${ }^{4}$ \\ From 4th European Headache and Migraine Trust International Congress: EHMTIC 2014 \\ Copenhagen, Denmark. 18-21 September 2014
}

\section{Background}

There are indications that a primary health care nurse may improve the treatment of migraine patients.

\section{Methods}

We conducted a non-randomized controlled prospective cohort study in primary care practices. In total 235 patients, diagnosed with migraine with or without aura according to ICHD- 2 criteria, between 18 and 65 years of age, were included. Patients with migraine treated only by their general practitioner (control group) were compared to patients managed by a nurse supervised by a general practitioner (intervention group). Primary outcome was the difference in referral rate to a neurologist because of migraine.

\section{Results}

In the intervention group, fewer migraine patients were referred to the neurologist (3.5\% vs. $29.8 \%$ in the control group, $\mathrm{p}=0.001$ ). The reduction in mean monthly headache days compared to baseline was apparent in the intervention group at 6 months (6.8 vs. 5.3 in the control group, $\mathrm{p}=0.006)$ and 9 months (4.7 vs. 2.1 days in the control group, $\mathrm{p}=0.006$ ). At 9 months there was no significant change in dichotomized HIT score, compared to baseline $(p=0.068)$. Change in satisfaction of patients with treatment compared to baseline after 9 months did not differ significantly between the control and intervention group $(\mathrm{p}=0.070)$.

\section{Interpretation}

The care administered by a primary care nurse supervised by a general practitioner resulted in less referrals to the neurologist and more headache-free days per month, but no change in HIT score. There was no

${ }^{1}$ Neurology, Isala clinic, Zwolle, Netherlands

Full list of author information is available at the end of the article difference in change from baseline in satisfaction scores between patients of both groups.

No conflict of interest.

\section{Authors' details}

${ }^{1}$ Neurology, Isala clinic, Zwolle, Netherlands. ${ }^{2}$ Department of General Practice, University Medical Center Groningen, Groningen, Netherlands. ${ }^{3}$ Department of Neurology, University Medical Center Groningen, Groningen, Netherlands. ${ }^{4}$ Department of Neurology, Isala clinic, Zwolle, Netherlands.

Published: 18 September 2014

doi:10.1186/1129-2377-15-S1-J18

Cite this article as: van den Berg et al:: EHMTI-0346. Do nurses improve migraine management in primary care? The Journal of Headache and Pain 2014 15(Suppl 1):J18.

\section{SpringerOpen ${ }^{\odot}$}

(C) 2014 van den Berg et al; licensee Springer. This is an Open Access article distributed under the terms of the Creative Commons Attribution License (http://creativecommons.org/licenses/by/2.0), which permits unrestricted use, distribution, and reproduction in any medium, provided the original work is properly cited.
Submit your manuscript to a SpringerOpen ${ }^{\circ}$ journal and benefit from:

- Convenient online submission

- Rigorous peer review

- Immediate publication on acceptance

- Open access: articles freely available online

- High visibility within the field

- Retaining the copyright to your article

Submit your next manuscript at $>$ springeropen.com 